\title{
THE EFFECTIVENESS OF INFANTRY SQUAD COMBAT AND PRE-COMBAT FORMATIONS FOR WARFIGHTING
}

\author{
Ludek RAK, Pavel ZAHRANICEK, Miroslav POLACH \\ University of Defence, Brno, Czech Republic \\ ludek.rak@unob.cz
}

\begin{abstract}
The article aims to describe experimental research into infantry squad pre-combat formations. It focuses on the most used formations, and addresses their advantages and suitability for various tactical situations. A highlighted feature of the experiment is the involvement of units with varying degrees of training as research subjects: from novices through to professional soldiers, from combat squads to instructors of the elite course of the ACR ground forces. The synthesized results can therefore be perceived as having universal validity. For broad-spectrum research of their properties and usability, each formation is evaluated in different terrains and different tactical situations. The presented data are usable in practice for training infantry, motorized airborne units, and in certain cases mechanized forces and combat support units. Research into this area of small-unit tactics is now even more progressive, since a significant number of tasks in conducting combat operations are being transferred to small units. This is at the expense of large troop formations, which are increasingly difficult to use in times of high-precision weapons and hybrid warfare. In certain situations even a small unit can perform tasks with operational ramifications. Moreover, in this area of tactics publications are very rare due to the low scientific interest and the inclusion of information falling under the 'classified information' of individual armies. The data presented in the article are set in their broader context, commented upon by the authors of the training, and described with the intention their inclusion in the training of troops.
\end{abstract}

Keywords: infantry training, pre-combat assembly, results of experiment, small-unit tactics

\section{Introduction}

The conduct of combat by small infantry units is currently a trend in modern operations. Even in stabilization operations, there is a visible effort to reduce the number of forces. Of course, in contrast to the equivalent mechanized formation, a small infantry unit lacks combat strength: what they have is concentrated only in small arms and a limited amount of equipment and ammunition. However, especially in the context of modern trends in reconnaissance, electronic warfare, and radiological reconnaissance, small formations of well- organized forces are an effective response to technological progress. These units are quickly available in the operating environment, more difficult to detect by enemy sensors, and so more difficult to destroy with high-precision weapons. Their deployment does not require huge support and provision, and the benefits of infantry fighting have been proven in several recent conflicts. Objectively speaking, infantry units are an important type of combat squad, and commanders may prefer these units over more powerful ones. Besides, mechanized, tank and support forces, too, 
must be masters of infantry tactics in case they are limited in operations by the inability to deploy vehicles or in extreme cases when vehicles are destroyed. Such a unit, or at least part of it, remains on the battlefield and either continues to perform the task or performs other tasks that allow for the use of infantry, or at least effectively acts against the enemy. For all this activity, a good knowledge of combat drills and the unit's synchronization of movement for a minimum number of basic combat manoeuvres are necessary.

\section{Methodology}

The starting point for the research were theses on US military regulations [4] [1]. After being published on the Internet, these sources have generally become a vital source of information for implementing small-unit tactics. The information they contain has often been compared with national practices and evaluated positively in terms of feasibility and functionality. Based on this regulation, follow-up books and manuals in the Czech language were published in the Czech Republic as instructional resources, which combat units themselves created for their own needs, e.g. [2][8], or as all-army training aids, e.g. [3]. Thanks to the possibilities of the subject 'Preparation in the field', it was possible to implement a diploma thesis [7]. This focused on the experimental scientific verification of knowledge concerning the pre-combat formations of infantry squads. Testing itself took place in the summer of 2018 and was carried out at the Březina military training area. A total of 18 model situations were implemented for various formations to determine the ability of units in predetermined pre-combat formations to recognize in time various enemy objects in the area, and respond to an enemy attack by direct fire. Prior to launching the experiment, the soldiers had one hour for synchronizing and preparing. It should be noted that in no case was a whole unit involved, but always members of one company who had not been synchronized before the experiment.

The experiment was participated in by firstyear students at the University of Defence without much experience in conducting combat activities, but with theoretical knowledge of the necessary scope. The second research sample included members of the combat company of the $44^{\text {th }}$ Light Motorized Battalion. The soldiers' length of service was five years on average, and the shortest period of service for one member was three years. The soldiers had a lot of practical experience implementing combat drills according to the customs of their unit. The third research sample was members of the training department of the prestigious Komando infantry course in VA Vyškov. These soldiers had been through an average of two foreign operations; length of service ranged from 9 to 22 years, during which time they had performed tasks in various combat units, with excellent results.

This segregation of research samples had a clear aim: to obtain truly unique results, usable for the widest possible range of types of infantry squads.

During the research, the following infantry pre-combat formations were tested:

- Column;

- Staggered Column;

- V;

- Wedge. Cf.: [1]

The entire research was carried out in undulating and partially wooded terrain with standard visibility of 100-200 metres. Neither the temperature nor any other hydro-meteorological conditions could skew the measurement because they were within the comfort range. Visibility was not reduced; the experiment was not limited by the action of other units at an immediate distance to the experimental measurement. Each unit realized all four formations in one section of the terrain, separately, and then verified the measured data in a comparable but different location. Comparable tactical incidents were prepared for each formation to provide the possibility of objectively 
measuring the same data. The tactical activities were realized with training ammunition, and markers acquainted with details of the experiment and the required activities were appointed to act upon the unit. The formations' realization of tactical activities was evaluated by an expert with a practically acquired, profound knowledge of the tactics of infantry squads. Based on the practical experience of all interested parties, a hypothesis of the whole experiment was formulated: $\mathrm{H} 1$ : The use of the wedge formation is more suitable than other pre-combat formations (column, staggered column, and V) in terms of the ability to search and destroy the enemy during a tactical move.

During the entire three-day testing, the soldiers involved were continuously questioned as to whether their ability to perform tactical operations had been reduced due to illness, fatigue, etc. In all cases with a negative result. So the units were fully eligible - within their skills - for the experiment. There was also no change in weather or visibility due to the constant weather conditions in the testing area.

\section{Results of experiment}

A considerable quantity of results were obtained during testing. Due to many factors, especially mistakes made by student-soldiers, mistakes in the squad command, and small mistakes made by markers, having an excellently trained instructor in the position of evaluator proved very justified. The ability of soldiers in formation to spot the enemy, and the ability to deploy into a combat formation that affords maximum firepower using the weapons of all soldiers in the team, were evaluated as the two most important parameters of the formations. The results are shown in Tab. 1. Results are always given here for both axes of movement both the initial and verification - and for each squad performing the activity. The resulting distances were measured with a laser rangefinder. The average spotting distances for a single enemy, a group of enemies, and a stationary vehicle are presented here. Again, these types of enemy forces were chosen in a maximum effort to obtain objective data by incorporating the most common types of enemy into the experiment. The measured data show that the staggered column formation seems to be the most appropriate for the ability to spot the enemy. On average, in this formation, soldiers were able to identify the enemy from a distance of $139 \mathrm{~m}$. Just behind this result was the wedge formation, with an average of $107 \mathrm{~m}$; the least suitable for enemy identification appeared to be the column formation. At the same time, the difference between the squads also manifested itself quite as expected. Students were able to identify the enemy at a distance $30 \%$ shorter than the other two types of units, which achieved a comparable result. Thanks to the Regular and Instructor Squads maintaining concentration, and thanks also to acquired habits in combat drills, these units were able to locate the enemy at the very edge of visibility. Also, in these units there was greater diversity in the individuals who were able to identify the enemy.

The second important factor was the time when the formations achieved the ability to open fire by all means in the direction of attack by the enemy. To keep matters simple, the directions of attack on the formation from the front and the sides (right, left) were used. No other angles were verified. Besides, these involve the most common and probable directions of attack upon a unit on the battlefield. The results are presented in Tab. 2. Deployment time was measured from the enemy's first shot. It was the speed of deployment into the combat formation that was perceived as the main determining factor in the effectiveness of the formation. During the realization of the activity, fundamental mistakes consisting in violating the principles of conducting combat, firing and movement, and use of the terrain, were evident in the 
'Student' formation. Thus the validity of the times achieved is ambiguous.

During movement, a number of problems arose for teams in the ' $\mathrm{V}$ ' formation. Very often the Student Squad and occasionally the Regular Squad were too stretched out, putting too much distance between the soldiers in the formation. The unit's communication and command were thereby considerably disrupted, and when crossing rugged terrain the soldiers lost track of the overall situation in the squad.

Overall, the following conclusions can be synthesized from the times achieved in Table 2. The wedge allows the fastest deployment into combat formation. The soldiers were able to realize the deployment in an average of 1.5 minutes; besides, the formation is very versatile. It responds almost as quickly to an attack on the front and side of the formation. The staggered column formation seems to be the most problematic. Not only did the soldiers need an average of 2.7 minutes to deploy, there is also a significant disproportion in deployment between when the front and side of the formation is attacked. Soldiers from the Regular Squad group achieved the fastest times in deploying the formation. It was clearly visible that their activity is very well automated. They were able to use the gaps in the formation properly and, in contrast to the Student Squad, blend the formation and not just open it. The Instructor Squad group achieved almost the same time. There was an obvious effort to deploy the formation prudently and effectively rather than achieve the fastest possible time. As with the Regular Squad, it was clear that everyone in the formation was sure exactly where the other unit members were. The Student Squad group achieved a $50 \%$ worse time on average, moreover with the mistakes described above in half of the cases.

Overall, based on experimentally verified data it can be said that the hypothesis was confirmed. When using the wedge formation, the soldiers achieved only average values in identifying the enemy, compared to other formations. However, this fact has a significantly lower weight than the ability to quickly and effectively deploy into a combat formation, more so when supported by the largest number of available weapons firing on the enemy from various sides. When realizing the wedge, even the least trained Student Squad committed the smallest number of tactical errors. The better-trained units were able to deploy the formation also by blending, which was significant with regard to the unit's covering and firing on the enemy in specific situations.

The $\mathrm{V}$ formation seems to be the most problematic. Not only did soldiers achieve below-average results in enemy identification when using it, but they were also below-average in deployment. The significant difference between deployment when the front and sides of the formation are attacked is also a significant handicap of the V. Tactical mistakes occurred during its realization, primarily made by less trained units. Also, concerning overall speed and the need for command interventions, the formation seemed to be the least effective. However, this evaluation does not deny the fact that this pre-combat formation may be appropriate in certain tactical situations. The overall results, including assigned weights, are shown in Tab. 3. The column and staggered column formations achieved very similar characteristics in the overall evaluation and are suitable for tactical movements. 
Table 1 Result of experiment, distance to detection of enemy Distance of detection of Enemy in depending on pre-combat formations

\begin{tabular}{|l|c|c|c|c|c|c|c|c|}
\hline \multirow{2}{*}{$\begin{array}{l}\text { Type of } \\
\text { squad/ } \\
\text { formation }\end{array}$} & \multicolumn{2}{|c|}{ Column } & \multicolumn{2}{c|}{$\begin{array}{c}\text { Staggered } \\
\text { Column }\end{array}$} & \multicolumn{2}{c|}{ Wedge } & \multicolumn{2}{c|}{ Vee } \\
\cline { 2 - 9 } & $1 . T e s t$ & $2 . T e s t$ & $1 . T e s t$ & $2 . T e s t$ & $1 . T e s t$ & $2 . T e s t$ & 1.Test & 2.Test \\
\hline Students sq. & $80 \mathrm{~m}$ & $75 \mathrm{~m}$ & $100 \mathrm{~m}$ & $110 \mathrm{~m}$ & $100 \mathrm{~m}$ & $90 \mathrm{~m}$ & $75 \mathrm{~m}$ & $90 \mathrm{~m}$ \\
\hline Regular sq. & $75 \mathrm{~m}$ & $125 \mathrm{~m}$ & $150 \mathrm{~m}$ & $150 \mathrm{~m}$ & $100 \mathrm{~m}$ & $135 \mathrm{~m}$ & $115 \mathrm{~m}$ & $125 \mathrm{~m}$ \\
\hline Instructor sq. & $100 \mathrm{~m}$ & $100 \mathrm{~m}$ & $175 \mathrm{~m}$ & $150 \mathrm{~m}$ & $125 \mathrm{~m}$ & $125 \mathrm{~m}$ & $120 \mathrm{~m}$ & $120 \mathrm{~m}$ \\
\hline
\end{tabular}

Table 2 Result of experiment, ability to go on the attack

\begin{tabular}{|c|c|c|c|c|c|c|c|c|}
\hline \multicolumn{9}{|c|}{ Time of expand to combat line } \\
\hline \multirow{2}{*}{$\begin{array}{l}\text { Type of } \\
\text { squad/ } \\
\text { formation }\end{array}$} & \multicolumn{2}{|c|}{ Column } & \multicolumn{2}{|c|}{$\begin{array}{l}\text { Staggered } \\
\text { Column }\end{array}$} & \multicolumn{2}{|c|}{ Wedge } & \multicolumn{2}{|c|}{ Vee } \\
\hline & 1.Test & 2. Test & 1.Test & 2.Test & 1.Test & 2.Test & 1.Test & 2.Test \\
\hline $\begin{array}{l}\text { Direct of } \\
\text { Enemy attack }\end{array}$ & $\begin{array}{l}\text { Left } \\
\text { side }\end{array}$ & Front & Front & $\begin{array}{l}\text { Left } \\
\text { side }\end{array}$ & $\begin{array}{l}\text { Right } \\
\text { side }\end{array}$ & Front & Front & Right side \\
\hline Students sq. & $1 \mathrm{~min} *$ & $3 \mathrm{~min}$ & $4 \mathrm{~min}$ & $2 \mathrm{~min}$ & $3 \mathrm{~min}$ & $1 \mathrm{~min} *$ & $3 \min ^{*}$ & $4 \min *$ \\
\hline Regular sq. & $1 \mathrm{~min}$ & $2 \mathrm{~min}$ & $4 \mathrm{~min}$ & $1 \mathrm{~min}$ & $1 \mathrm{~min}$ & $1 \mathrm{~min}$ & $1 \mathrm{~min}$ & $3 \min$ \\
\hline Instructor sq. & $1 \mathrm{~min}$ & $3 \mathrm{~min}$ & $3 \mathrm{~min}$ & $2 \mathrm{~min}$ & $1 \mathrm{~min}$ & $2 \mathrm{~min}$ & $1 \mathrm{~min}$ & $2 \mathrm{~min}$ \\
\hline
\end{tabular}

Table 3 Overall results using the method of weighting criteria

\begin{tabular}{|l|c|c|c|c|c|c|c|c|}
\hline Distance of detection of Enemy in depending on pre-combat formations \\
\hline $\begin{array}{l}\text { Type of } \\
\text { squad/ } \\
\text { formation }\end{array}$ & \multicolumn{2}{|c|}{ Column } & \multicolumn{2}{|c|}{$\begin{array}{l}\text { Staggered } \\
\text { Column }\end{array}$} & \multicolumn{2}{c|}{ Wedge } & \multicolumn{2}{c|}{ Vee } \\
\cline { 2 - 10 } & Eval. & Weight & Eval. & Weight & Eval. & Weight & Eval. & Weight \\
\hline Identification & 4 & 1 & 1 & 1 & 2 & 1 & 3 & 1 \\
\hline Go to attack & 2 & 2 & 4 & 2 & 1 & 2 & 3 & 2 \\
\hline $\begin{array}{l}\text { Probability of } \\
\text { mistakes }\end{array}$ & 1 & 0,5 & 1 & 0,5 & 1 & 0,5 & 2 & 0,5 \\
\hline $\begin{array}{l}\text { Speed, } \\
\text { leadership }\end{array}$ & 3 & 0,5 & 2 & 0,5 & 1 & 0,5 & 4 & 0,5 \\
\hline Total/Rank & 10 & $2-3$ & 10,5 & $2-3$ & 5 & 1 & 12 & 4 \\
\hline
\end{tabular}

*) Tactical mistakes when deploying a formation

\section{Conclusion}

In every operation, whether planned using a variety of methods, controlled by different levels of command, or whatever the specific set of variables and unknown factors may be, it will always be teams that will bear the brunt of the fight against the enemy. There is an ancient Roman maxim stating that no territory is conquered where a soldier's foot is not set. It is therefore necessary to scientifically underpin the deployment of modern means and technologies, and create cogent studies to support typical combat units, including infantry squads, which will still form the core of the operational line-up for many years. The results of this study may be significant for the development and retention of scientific and military information in the field of tactics, given the number of stakeholders, the variety of methods used, and the experimental verification. The involvement of experts in small-unit tactics, especially for evaluating the activities of individual research samples, seemed very effective. Moreover, the whole study was supported by several 
expert interviews, which identified the probable results very correctly in advance. However, the presented study is only one of many scientific works that contribute to the development, argumentation, and revision of tactics of small units in the Army of the Czech Republic.

\section{Acknowledgements}

I would like to thank Ensign Tomáš Kotouč and Lieutenant Tomáš Kotouč for realization of the experiment.

\section{References List}

[1] WADE, Norman M. a Christopher LARSEN. STUS2: The Small Unit Tactics

[2] Smartbook. 2nd Edition. Washington, DC: The Lightning, 2017. ISBN 978-1-

[3] 935886-64-8.

[4] LÍBAL, J. Přŕručka pro velitele družstev a čet: Taktika malých jednotek, díl I. - bojové patrolování. Chrudim, 2012.

[5] Pub-31-11-01: Taktika družstva. Praha: Správa doktrín ŘeVD, 2008.

[6] SH 21-76: RANGER HANDBOOK. Fort Benning, Georgia: United States Army Infantry School, 2011.

[7] KOTOUČ, Tomáš. Možnosti jednotlivých sestav pěšího družstva při vyhledávání a ničení nepřítele. Brno, 2019. Diplomová práce. Univerzita obrany. Vedoucí práce Rak Luděk.

[8] RAK, Luděk. Příprava v poli I.: studijní pomůcka. Brno: Univerzita obrany, 2018. ISBN 978-80-7582-073-0. 